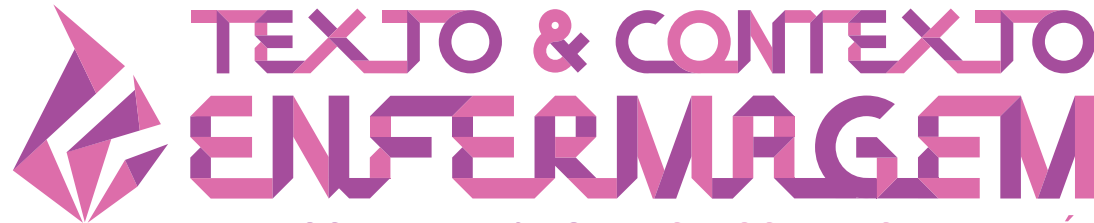

TEXT \& CONTEXT NURSING TEXTO \& CONTEXTO ENFERMERÍA

\section{COPING STRATEGIES USED \\ BY HOSPITAL EMERGENCY NURSES}

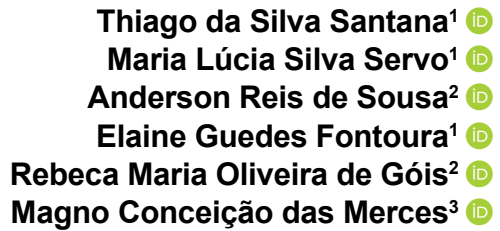

${ }^{1}$ Universidade Estadual de Feira de Santana, Departamento de Saúde. Feira de Santana, Bahia, Brasil. ${ }^{2}$ Universidade Federal da Bahia, Escola de Enfermagem, Programa de Pós-Graduação em Enfermagem e Saúde.

Salvador, Bahia, Brasil.

${ }^{3}$ Universidade do Estado da Bahia, Departamento de Ciências da Vida. Salvador, Bahia, Brasil.

\begin{abstract}
Objective: to analyze the Coping Strategies used by hospital emergency nurses.

Method: qualitative study with a descriptive exploratory approach, conducted with 15 nurses from an emergency hospital department in the public healthcare network of a municipality in the state of Bahia, Brazil. The semistructured in-depth interview was used. Data were collected from April to June 2017. The findings are based on the collective subject discourse method, supported by the theoretical Coping framework.

Results: the presence of stress generating situations is significant in the work of hospital emergency nurses, causing social, labor and psychosomatic repercussions to emerge emotional or psychiatric disorders that affect the body's functionality, including physical repercussions. The development of Coping Strategies arises in the face of the need to cope with stressors. They involve the use of personal, social and spiritual resources, and reveal themselves in positive and/or negative responses. The discourse revealed that, when focused on the problem (management of the stressor), they seek to strengthen social support, plan their daily activities and establish a dialogic and mutual help relationship with the team; when centered on emotion (regulation of emotions or distress), they exercise the search and maintenance of emotional control, practice self-control, move away from the stressor element and invest in physical activity and leisure practices.

Conclusion: the nurse employs different Coping Strategies which are essential and indispensable to avoid increasing stress levels and triggering negative repercussions. The strategies undertaken are now centered on the problem, or emotion.
\end{abstract}

DESCRIPTORS: Coping strategies. Nurse. Occupational stress. Emergency health services. Public hospitals. 


\section{ESTRATÉGIAS DE COPING UTILIZADAS POR ENFERMEIRAS DE EMERGÊNCIA HOSPITALAR}

\section{RESUMO}

Objetivo: analisar as Estratégias de Coping utilizadas por enfermeiras de emergência hospitalar.

Método: estudo descritivo, exploratório e qualitativo, realizado com 15 enfermeiras de uma emergência hospitalar da Rede Pública de um município do estado da Bahia, Brasil. Utilizou-se a entrevista semiestruturada em profundidade. A coleta de dados ocorreu no período de abril a junho do ano de 2017. Os achados estão ancorados no método do Discurso do Sujeito Coletivo, suportados pelo referencial teórico de Coping.

Resultados: a presença de situações geradoras de estresse é marcante no trabalho da enfermeira de emergência hospitalar, fazendo emergir repercussões sociais, laborais e psicossomáticas, desarranjos emocionais ou psiquiátricos que afetam a funcionalidade do corpo, abarcando as repercussões físicas. O desenvolvimento de Estratégias de Coping surge frente à necessidade de enfrentamento aos estressores. Envolvem o emprego de recursos pessoais, sociais e espirituais, e revelam-se em respostas positivas e/ou negativas. O discurso revelou que, quando centradas no problema (gestão do agente estressor), buscam o fortalecimento do suporte social, planejam suas atividades diárias e estabelecem relação dialógica e de ajuda mútua com a equipe; quando centradas na emoção (regulação de emoções ou angústias), exercitam a busca e a manutenção do controle emocional, praticam o autocontrole, afastam-se do elemento estressor e investem em práticas de atividade física e lazer.

Conclusão: a enfermeira emprega diferentes Estratégias de Coping, sendo essenciais e indispensáveis para evitar a elevação dos níveis de estresse e o desencadeamento de repercussões negativas. As estratégias empreendidas evidenciadas ora estão centradas no problema, ora na emoção.

DESCRITORES: Estratégias de enfrentamento. Enfermeira. Estresse ocupacional. Serviços de saúde de emergência. Hospitais públicos.

\section{ESTRATEGIAS DE COPING QUE UTILIZAN LAS ENFERMERAS DE URGENCIAS HOSPITALARIAS}

\section{RESUMEN}

Objetivo: analizar las Estrategias de Coping que utilizan las enfermeras de urgencias hospitalarias.

Método: estudio descriptivo, exploratorio y cualitativo, realizado con 15 enfermeras de un servicio de emergencia de un hospital público de un municipio del estado de Bahía, Brasil. Se utilizó la entrevista en profundidad semiestructurada. La recolección de datos se llevó a cabo de abril a junio del año 2017. Los hallazgos están anclados en el método del Discurso Colectivo del Sujeto, sustentado en el marco teórico de Coping.

Resultados: destaca la presencia de situaciones generadoras de estrés en el trabajo del enfermero de urgencias hospitalarias, dando lugar a repercusiones sociales, laborales y psicosomáticas, Trastornos emocionales o psiquiátricos que afectan la funcionalidad del cuerpo, englobando las repercusiones físicas. El desarrollo de Estrategias de Coping surge ante la necesidad de afrontar los factores estresantes. Implican el uso de recursos personales, sociales y espirituales, y se revelan en respuestas positivas y/o negativas. El discurso reveló que, al enfocarse en el problema (manejo del estresor), buscan fortalecer el apoyo social, planificar sus actividades diarias y establecer una relación dialógica y de ayuda mutua con el equipo; cuando se centran en la emoción (regulación de emociones o angustia), ejercen la búsqueda y mantenimiento del control emocional, practican el autocontrol, se alejan del elemento estresante e invierten en prácticas de actividad física y ocio.

Conclusión: la enfermera emplea diferentes Estrategias de Coping, esenciales e indispensables para evitar elevar los niveles de estrés y desencadenar repercusiones negativas. Las estrategias emprendidas evidenciadas se centran a veces en el problema, a veces en la emoción.

DESCRIPTORES: Estrategias de coping. Enfermero. Estrés laboral. Servicios de salud de emergencia. Hospitales públicos. 


\section{INTRODUCTION}

The technological organization of the nurses in the Hospital Emergency Unit (HEU) is highly dynamic and their daily activities involve the provision of complex care, as continuous care involves coordination actions and the provision of care to people in clinical deterioration at risk of life. ${ }^{1}$ Stress comes from the interaction of the individual with the factors of the environment, when he perceives challenging situations as surplus to their coping capacity ${ }^{2}$.

The urgent need to meet, in a short period of time, the multiple tasks emerged in the context of emergencies, involving both the presence of the surprise factor, which will require the professionals agility and precision to ensure immediate help, as well as the need to allocate attention to family members ${ }^{3}$. These phenomena, which act separately or together, can lead to impairments in professional performance, in the occurrence of errors and in the physical and mental illness of nurses.

A Brazilian study with 109 nursing professionals in the hospital emergency indicates the presence of stress-generated incapacitations ${ }^{4}$. In convergence with the Brazilian context, studies conducted in North America and Australia show that professional stress is an expressive public health problem, endemic in the healthcare field, which reveals concerns of national and international agencies and institutions, considering its potential to cause severe impacts on worker health ${ }^{5-6}$.

The work of nurses in HEU is impacted by social phenomena (occurrence of mass disasters, accidents with multiple victims, attacks, bioterrorism, terrorism, environmental disasters, pandemics, such as Covid-19), which make the performance of work activities even more stressful and challenging. Mediated by these complex contexts, physical, psychosocial, environmental and organizational consequences are present ${ }^{7}$, requiring nurses to cope with stressors.

The continuous exposure of nurses in the HEU to stressors at work causes changes in work performance, which can reduce satisfaction and decrease efficiency and productivity ${ }^{8}$. This scenario requires nurses to use coping strategies on a daily basis.

Thus, in an attempt to combat stress and minimize adverse effects, coping strategies emerge as cognitive and behavioral mechanisms and attitudes that lead to adaptation to stressful situations with the potential to modify, control, tolerate or reduce their evolution. As a way of structuring coping strategies $^{9}$, it is classified as coping centered on problem and emotion, which makes the levels and orders of development of human coping to stress noticeable.

Thus, the identification of coping strategies used by nurses in the face of stressors present in HEU is a significant tool to recognize potential vulnerabilities and occupational risks, which affects the provision of substantial information for the development of strategic actions to cope with and minimize impacts $^{10}$. In addition, it is a relevant organizational, educational and scientific component directed to the world of nursing and health work in the hospital environment.

Although there are scientific productions that deal with the stressful situations experienced by nurses and the nursing team in the context of hospital emergencies, there are few studies that deal with the coping strategies used in the professional context, which justifies the development of this study. Considering the panorama presented, this study was guided by the research question: What are the coping strategies used by hospital emergency nurses? In order to answer this question, the study aims to analyze the coping strategies used by hospital emergency nurses. 


\section{METHOD}

This is a descriptive, exploratory study with a qualitative approach, carried out in the HEU of a general hospital part of the Public Health Network of a municipality in the state of Bahia, Brazil and stands out in the organization of Health Care Networks and in urgent, emergency and trauma care, considered a reference for services of medium and high complexity in the diverse areas of healthcare.

The study included 15 nurses who met the inclusion criteria: performed patient care and/or had a managerial position in the HEU; more than six months of work experience in the HEU of the institution under study. Nurses who were on vacation, maternity leave, sick leave and other orders and who were not in emotional conditions to participate in the study were not included in the study. There was no refusal on the part of the nurses invited to participate in the research.

Regarding participant invitation, visits were made at the hospital institution during meetings which were organized with the intention of explaining the research to them. After the acceptance and consent of the participants, the Informed Consent Form (ICF) was presented, which was read and signed.

Data collection was performed from April to June 2017, by researchers with masters and doctoral degrees and expertise in the area, who were trained in the method, data collection and processing techniques, and who did not have direct links with the participants. At the time of the data collection, the main researchers, one male and the other female, performed professional activities in the area of teaching and nursing care, in relation to interest and approximation according to the object of study investigated.

An in-depth semi-structured interview was conducted, guided by a previously elaborated script that includes participant characterization and data related to coping strategies, centered on triggering questions, namely: tell me about stressful situations in the HEU? Tell me about the coping strategies you have adopted in order to deal with the stressful situations experienced in the HEU? The participants were informed about the researcher's presentation, regarding the intentions, professional insertion and future purposes regarding the research field and practices developed.

The interviews took place in the hospital environment, in a room provided by the nursing coordination, only with the presence of the interviewee and the responsible researcher, at their availability and did not compromise the quality of the interview or the service provided. The interviews were only audio recorded and had an average duration of 40 minutes. They were made available to the participants for the purpose of analysis and validation, and, thus, after favorable feedback, they were considered for the results. Afterwards, they were transcribed, and submitted to organization and systematization using the Nvivo11 software, which allowed the codification, creation of theoretical nodes/codes, and design of discursive analytical categories and subcategories. There were no repeated interviews. The Consolidated Criteria For Reporting Qualitative Research (COREQ) guidelines were adopted in order to ensure rigor in qualitative research.

The structuring of the theoretical and methodological analysis that guided the study is based on the Collective Subject Discourse (CSD) method, which is rooted in the Theory of Social Representations, which allows revealing own methodological figures, such as: Key Expressions (KE), adjacent data present in the speeches, Central Ideas $(\mathrm{Cl})$ and Anchorage, nuclear data representing the study, materialized from the analysis of empirical data of verbal nature, taken from the participants' statements. These data were submitted to systematic and standardized procedures, in order to reveal similar discourses of meaning, elaborating the synthesis-discourses, thus expressing the idea of a collectivity ${ }^{11}$. Thus, the KEs were extracted, and the $\mathrm{Cl}$ were grouped and emerged and, later, the construction of the Synthesis Discourses of the collectivity. The corpus was submitted to interpretation from coping theoretical framework, which comes from Social, Clinical and Personality Psychology, adopted in this study 9 . 
The autonomy and anonymity of the participants, as well as the reliability and veracity of the collected data, were guaranteed throughout the operationalization process of the research. The research was submitted to the research ethics committee. The participants received the corresponding description of the method, namely: CSD of nurses.

\section{RESULTS}

The participants of this study were female, nurses, aged between 25 and 32 years, self-reported as white race/color, with lato sensu training in the area of Accident and Emergency Nursing ( $n=07)$, Intensive Care Unit (ICU) ( $n=06)$, Public Health $(n=01)$ and Collective Health $(n=01)$. They have an average time of six years of experience in the area and have, for the most part, two formal work links, with a total workload of more than 44 hours per week.

The nursing work activities in the HEU is surrounded by stressful situations, which, in turn, imply psychosomatic, social and labor repercussions revealed in the collective discourse of nurses working in this location, requiring the development of coping strategies.

Chart 1 specifies the stressful situations in the work of the nurse working in the HEU.

Chart 1 - Stressful situations in the work of the nurse of the Hospital Emergency Unit.

Feira de Santana, Bahia, Brazil, 2017.

\begin{tabular}{|c|}
\hline Stressful situations \\
\hline $\begin{array}{l}\text { Situation 01: Inadequate physical structure: Defining characteristics - absence of areas defined for } \\
\text { priority care and the presence of stretchers in the corridor. }\end{array}$ \\
\hline $\begin{array}{l}\text { Situation 02: Organizational/administrative fragility: Defining characteristics - absence of a reception } \\
\text { service with risk classification, lack of bed regulation resolution, inefficiency in performing diagnostic tests } \\
\text { and lack of medical specialties. }\end{array}$ \\
\hline $\begin{array}{l}\text { Situation 03: Lack of material resources: Defining characteristics - lack of basic items for care } \\
\text { procedures. E.g. vacuum aspiration vial, catheters, drains, medications and support cables for } \\
\text { hemodynamic monitoring; lack of diagnostic equipment. }\end{array}$ \\
\hline $\begin{array}{l}\text { Situation 04: Overcrowding of the hospital emergency unit: Defining characteristics - excessive } \\
\text { number of patients, insufficient number of beds and lack of vacancies in hospitalization units. }\end{array}$ \\
\hline $\begin{array}{l}\text { Situation 05: Work overload: Defining characteristics - excess of patients, clinical condition/deterioration } \\
\text { and insufficient staff dimensioning. }\end{array}$ \\
\hline $\begin{array}{l}\text { Situation 06: Weaknesses in medical regulation: Defining characteristics - weaknesses in the } \\
\text { resolution and governability of patients' health demands, slowness and bureaucratization of the team, } \\
\text { disorganization of the bed management sector. }\end{array}$ \\
\hline $\begin{array}{l}\text { Situation 07: Lack of Human resources: Defining characteristics - absence of professionals in the area of } \\
\text { Social Work, Psychology and Physiotherapy and limitation of medical specialists. Insufficient nursing staff. }\end{array}$ \\
\hline $\begin{array}{l}\text { Situation 08: Interprofessional conflicts: Defining characteristics - conflicts with the medical team - } \\
\text { weaknesses in the fulfillment of medical duties (e.g., triggering the medical professional in comfort during } \\
\text { the shift). }\end{array}$ \\
\hline $\begin{array}{l}\text { Situation 09: Disorganization of the work process: Defining characteristics - folds, lack of compliance } \\
\text { with work agenda, inadequate hospitalization of patients in the sector, issues in the internal regulation of } \\
\text { patients. }\end{array}$ \\
\hline $\begin{array}{l}\text { Situation 10: Criticality of patients: Defining characteristics - high demand of hospitalized patients } \\
\text { with high level of complexity (e.g., polytrauma, traumatic brain injury, exogenous intoxication, Acute } \\
\text { myocardial infarction, cerebral vascular accident, automobile accidents and firearm injuries) and the } \\
\text { development of high complexity nursing procedures (e.g., drains, administration of vasoactive drugs, aid in } \\
\text { intubation and mechanical ventilation). }\end{array}$ \\
\hline
\end{tabular}


Chart 1 - Cont.

Stressful situations

Situation 11: Failure to support nursing supervision: Defining characteristics - ignorance about the work process of supervision and relocation of professionals from one sector to another when the folds occur.

Situation 12: Family member requests: Defining characteristics - companions and patients requests in relation to the performance of tests and procedures of high complexity that were not performed within the deadline established by the team, and delay in medical evaluations.

Chart 2 presents the repercussions generated by stressors in the work of nurses working in HEU.

Chart 2 - Repercussions generated by stressors in the work of the nurse of the Hospital Emergency Unit. Feira de Santana, Bahia, Brazil, 2017.

Repercussions caused by stressors

Social repercussions: Emergence of interprofessional conflicts, family, relationship and marital conflicts influenced by stress at work. Social isolation.

Occupational repercussions: Interferences in the quality and performance of work activities and occupational disabilities.

Psychosomatic repercussions: Feelings of anguish, impotence, depersonalization, apathy, discouragement, bad mood, sadness, hopelessness, unhappiness, depression, incompleteness, internal conflicts, suffering, lack of professional recognition, devaluation, stress, emotional imbalance and anxiety, exhaustion, frustration, body aches and pains, headache, gastritis, tachycardia and hypertension.

The discourse revealed that the nurses of HEU, when suffering from the repercussions caused by stress at work, employ coping strategies focused on emotion and on the problem, consistent with the coping model $^{9}$ proposed in this study, as provided by Chart 3 below:

Chart 3 - Coping Strategies. Feira de Santana, Bahia, Brazil, 2017.

\begin{tabular}{|c|c|}
\hline Strategy & Statement \\
\hline $\begin{array}{l}\text { Problem- } \\
\text { focused } \\
\text { strategy: }\end{array}$ & $\begin{array}{l}\text { Every nurse has a different way of dealing with stress, I've gotten used to it, I've worked on my } \\
\text { emotions, I've learned to live with it here, there are times when I can't totally disconnect from } \\
\text { the emergency, because of the stressors, I accept reality as it presents itself, I try to keep calm } \\
\text { and control of the situation, I know what l'm doing, have security and try to act rationally in } \\
\text { order to provide the best patient care, it makes all the difference. Here in the emergency unit, } \\
\text { we work together, we know that we do not work alone, we always depend on each other, so I } \\
\text { maintain a good relationship within my group, the nursing team and with other professionals } \\
\text { as well, doctors and physiotherapists, it is a way for us to work better, on the basis of dialogue } \\
\text { to try to solve day-to-day problems, such as the lack of materials and equipment and deal with } \\
\text { bad working conditions. I plan my activities and work with priorities, which is more urgent, I have } \\
\text { done what is within my ability, I try to maintain a relationship of transparency with patients and } \\
\text { family members, I supervise the sector, I participate in meetings, training, I am always studying } \\
\text { to improve my knowledge. I vent with colleagues, family members, open my heart, I've asked to } \\
\text { change sector a few times, I've cried several times here in the emergency room. }\end{array}$ \\
\hline
\end{tabular}


Chart 3 - Cont.

\begin{tabular}{|l|l|}
\hline Strategy & \multicolumn{1}{c|}{ Statement } \\
\hline Emotion- & $\begin{array}{l}\text { Nowadays, when I leave my shift, I try to leave all the problems related to work here. In the first } \\
\text { few years, I couldn't disconnect, today, I try to work everything out here, I try to separate things, } \\
\text { I don't talk or think about them, I try not to take anything home. I have a little daughter, for me } \\
\text { maybe my therapy is to spend more time with her. I try to have some leisure moments in order } \\
\text { strategy: } \\
\text { to have a healthy life, do physical activity and run four times a week, do training courses, try to } \\
\text { participate in meetings and family events. I participate in meetings with colleagues outside the } \\
\text { hospital to talk about our personal life outside the hospital context to try to reduce stress. I ask } \\
\text { God for support because we have many problems not only in the emergency room but in the } \\
\text { whole hospital, but this is the moment that we have to rest and ask God to help. }\end{array}$ \\
\hline
\end{tabular}

The development of coping strategies arises when they are faced with the need to cope with the stressors present in nursing work in the HEU. They use personal, social and spiritual resources, and are revealed in positive and negative responses after the development of coping strategies, as illustrated in the following explanatory model (Figure 1).

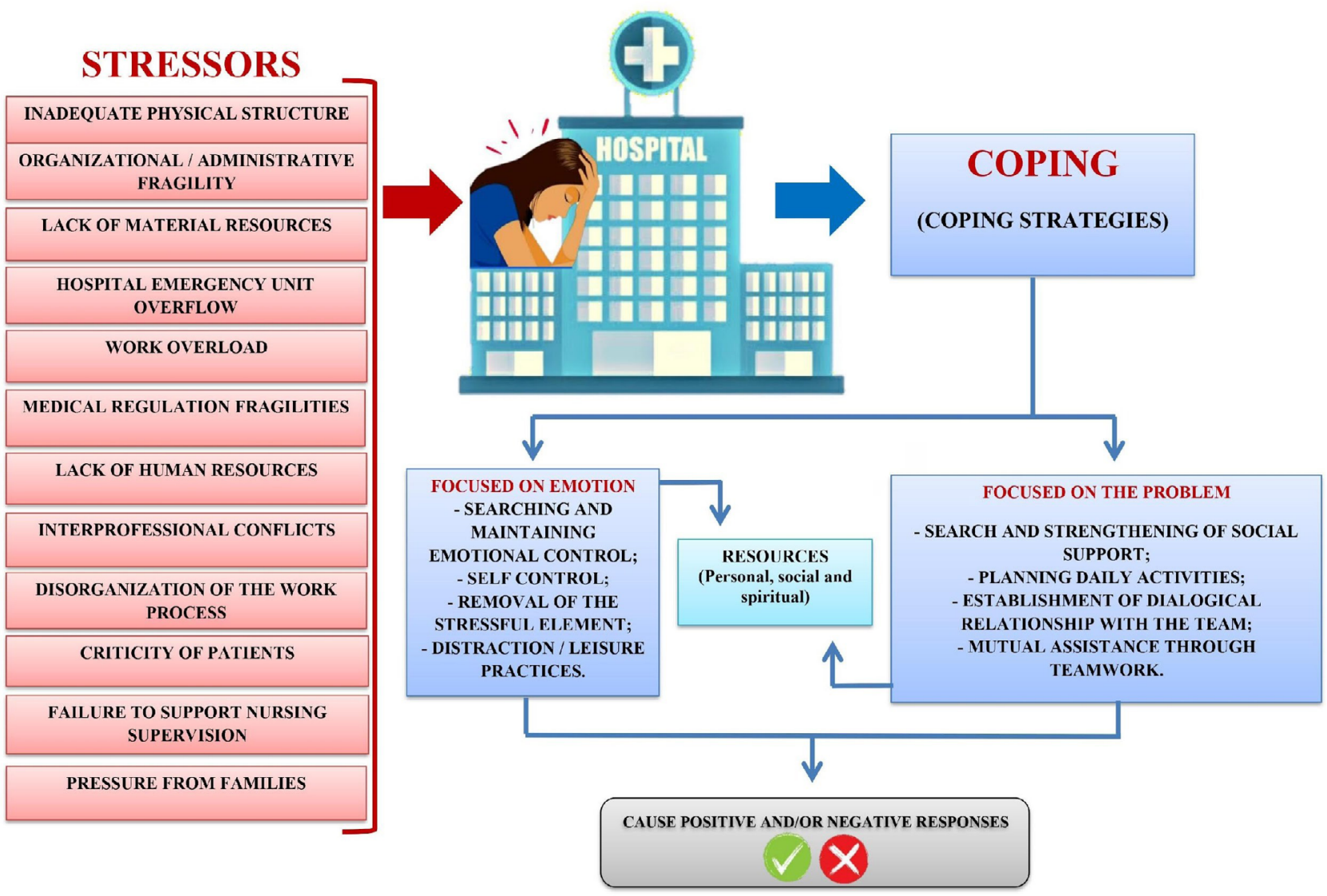

Figure 1 - Explanatory model of coping strategies used by nurses of a hospital emergency unit.

Feira de Santana, Bahia, Brazil, 2017. 


\section{DISCUSSION}

Stress is triggered when there is a break in the internal balance of an organism, i.e., when situations occur that irritate, frighten, excite, confuse or bring much happiness to the person. Faced with this imbalance, the body has to adapt to the moment, survive this threat and overcome the challenge ${ }^{12}$.

Stressors are situations, events or stress-causing agents. Its definition goes through a subjective individual observation mediated by the cognitive and social aspect ${ }^{12-13}$. The stressors evidenced in this study are related to the physical structure of the unit, organizational dynamics, lack of human resources, equipment and materials, interpersonal relationships, work overload, among others. Such situations can cause stress in nurses working in the HEU, since they will have to mobilize new energy sources in order to resume internal homeostasis, and adapt to changes.

Thus, stressful experiences can enable personal development, in addition to improving the physiological and psychological state, promoting greater personal performance and well-being ${ }^{9}$. However, this is only possible when stressors are perceived by the individual as opportunities for growth and responses to stress are evaluated as functional and adaptable, which, in turn, can promote active coping and thrive under adversity ${ }^{14}$.

The permanence of stressors and the consequent imbalance of the organism, as well as the non-use of coping mechanisms, can negatively interfere with the physical and mental health of these professionals as well as with their work process.

The CSD drew attention to the most varied forms of stressful situations. Facing them becomes a challenge for future improvement in the management of stress for the nurses in the HEU. Thus, the use of stress coping strategies are effective and are essential and indispensable measures to avoid increasing stress levels, triggering negative repercussions and adverse effects related to the work process ${ }^{1}$.

Thus, when nursing management analyzes the needs of the workers in the hospital environment, it increases the potential chances of interventions related to the problem, by detecting the stressors inherent to work, and by revealing the performance of professionals in the work environment related to the triggering of stress and its respective repercussions ${ }^{15}$. Therefore, it is recommended that nurse managers/nursing directors seek to support regarding learning about how to work to cope with stress effectively and how to manage the responses and repercussions resulting from stressful demands.

The repercussions generated by stressors in the work of the HEU nurse occur through the high stress load from multiple sources. The CSD revealed psychosomatic repercussions, manifested by emotional or psychiatric disorders that affect the functionality of the body, including the physical repercussions ${ }^{16}$, social and labor generated by continuous exposure to stressors.

Furthermore, these disruptive phenomena caused by the emergence of stress in the nursing work process impose negative repercussions not only on nurses, but also on nursing techniques ${ }^{17}$. These factors are permeated by stress that leads to the physical and mental illness of the professional ${ }^{18}$, and trigger social and psychological impacts, affecting the quality of life ${ }^{19}$.

Managers and nurses should plan health care, including the evaluation and follow-up of professionals regarding events that can negatively affect their physiological, psychological, relational and organizational areas ${ }^{19}$, through the perception, encouragement and early recognition of problems or sufferings, which can alter work dynamics and even influence patience care ${ }^{10}$.

Frequent exposure to stressful situations that lead to distress (stress due to long exposure to threatening situations) triggers negative feelings, depression, stress, anxiety and physical illness, which cause adverse effects that are not limited to the scope of work and extrapolate to other dimensions of life such as family, relationships, marital and social isolation conflicts ${ }^{20}$. Consequently, the impacts caused by such situations affect and compromise the quality and performance of work activities, 
reflecting occupational disabilities and interfering in well-being ${ }^{4}$. Therefore, it is essential to recognize that not coping with stress can lead individuals to miss opportunities for performance and growth. Thus, during stressful situations, an effective conduct is to manage the responses to stress. Thus, supporting leadership has been fundamental in this process ${ }^{7,19}$.

The mechanisms used to cope with stress by nurses in this study are translated into coping strategies developed inside and outside the work environment, and aim to avoid or minimize the negative repercussions caused by stress. They are efforts to adapt to the different situations resulting from the intimate and routine contact with stressors ${ }^{14,21}$.

With regard to the work scenario, nurses perform adaptation actions characterized by acceptance of reality, self-control, teamwork, promotion of a welcoming environment, dialogue with a multidisciplinary team for problem solving, planning daily activities, transparent relationship with patients and family, supervision and participation in meetings. Such strategies are based on positive responses that verify personal and professional improvement and allow to add efforts to adapt to stressful situations in order to reduce the occurrence of work related stress ${ }^{1}$.

The statement also revealed the existence of investments in training and studies to improve their knowledge and apply them to their clinical practice, which can be seen as an effective strategy to be explored. This finding reveals sources used by nurses as way to be able to deal with work-related problems. The direct confrontation through dialogue with family members and co-workers and the wish to change sector, in order to redefine the stressful element, has been employed by these nurses as a way found to deal positively with the stressful situation.

Regarding the strategies used outside the work environment present as characteristics, distance, avoiding the problem and the search for emotional support. Highlighting the strengthening of family and social bonds, activities directed to psychological well-being and body care, as well as leisure activities, intellectual investment and professional qualification, and the search for spiritual support to strengthen belief and faith. The use of coping strategies outside of the work environment suggests a complementarity to the cognitive and behavioral capacities built internally by the psyche of these professionals ${ }^{9}$.

In this context, similar results were found in a research that sought to identify stressors and coping strategies developed by nurses working in an emergency department, who located the development of strategies applied at work and outside. It was possible to identify strategies such as dialogue with the team/professionals, empathy with others, mutual help and conflict resolution in the work environment ${ }^{22}$. On the other hand, in a complimentary character, the strategies developed by the nurses were: physical activity/leisure, meditation, self-control, enjoying silence, being with the family and externalizing a feeling of valorization of life. In this respect, the literature has pointed out that using these strategies and associating with the management of occupational stress, improvements in work performance with the guarantee of health preservation and expansion, quality of life can be achieved ${ }^{19,22}$.

The statements reveal that the HEU nurses exercise different coping strategies, and that there is an interconnection between them, recognizing that they are now focused on the problem (management of the stressful agent), or are centered on emotion (regulation of emotions or anguish) ${ }^{9}$. When the findings are rooted in the coping reference ${ }^{9}$, it is noted that the different structures of coping strategies may instinctively intersect, from the employment of individual faculties and competencies, acquired throughout life and professional experience.

Problem-focused coping refers to the management of adversity that is causing the suffering ${ }^{9,23}$. Emotion-focused coping strategies are: (a) distancing - efforts to move away from the situation or a more positive view of it; (b) avoidance - efforts to avoid the problem; (c) self-control - efforts to dominate feelings and actions; (d) acceptance of responsibility - recognition of its role in relation to 
the problem, in order to improve or circumvent the situation; (e) seeking social support - efforts to seek support and (f) positive reassessment - efforts to create a positive meaning to the situation ${ }^{14,21}$.

From this perspective, a study conducted in São Paulo, Brazil, identified as principally adaptive coping strategies, problem solving, problem-focused coping and positive reassessment (emotional control) and social support, coping focused on emotion, both employed in the same context under stress or agents similar to those presented in this study ${ }^{8}$. However, the literature highlights that strategies aimed at controlling the problem may have a protective function against stress in the work environment, since it allows the modification of the situation, both by trying to remove the problem, and by developing alternative solutions to reduce the impact capacity of the stressing agent ${ }^{10,13,21,24}$.

Among the actions focused on the problem, the collective discourse of the nurses of the HEU reveals active approach strategies with the source of stress as a form of planning and problem solving. These results demonstrate the presence of stress not only in the actions and/or activities of the health work process, but also translate characteristic elements specific to the nursing work process ${ }^{3}$.

It is important that HEU nurses create coping strategies that act on specific components of training, such as supervision, which is understood as an important management tool to be performed in this sector, as also being a coping strategy capable of qualifying the professional, developing team member potentialities, in order to promote quality and safe care to users of the health system ${ }^{25}$. Coping with situations imposed by work becomes a power limit for future improvements, considering the search for resolution in issues related to working conditions, as they avoid triggering stress.

Findings in other countries corroborate the results of this study and add that time management, team dialogue (effective communication), delegation of activities and expression of feelings rather than repressing them, present themselves as effective actions in the management and coping with stress ${ }^{6-7}$.

The balance in the applicability of coping strategies needs to be shared as a co-responsibility, through the division of responsibilities between the professional and the institution, in order to promote the reduction of stress through education for the recognition and use of coping strategies. ${ }^{10}$ However, regarding the $\mathrm{HEU}$, in which exposure to stressors occurs on a daily basis, coping strategies need to be positive and satisfactory, in order to give new meaning to the stressful element through the adaptation of the professional to the reality that now presents itself, making the work teams increasingly knowledgeable and prepared to act in stressful environments ${ }^{3}$.

In order to cope with stressful situations, a more effective approach is to optimize responses to stress, i.e., to promote adaptive responses motivated by the approach and control to the stressor element, as a form of planning and problem solving ${ }^{26}$.

It should be noted that the higher the level of control at work, the greater the probability of nursing professionals using active strategies to deal with stress ${ }^{4}$. Therefore, investing in strategies that add to efforts to reduce stress and damage to health in the hospital emergency environment contribute so that nurses act as active agents in day to day activities in the HEU, participating and conducting training, realistic simulations, training courses and receiving psychosocial and occupational therapeutic support.

In this way, it is observed that the individual can present a dynamic repertoire for coping with occupational stress through individual and/or collective actions ${ }^{3}$. It is necessary that organizations invest in interventions focused on the worker as a way to contribute to the prevention of illness at work, acting as an auxiliary tool in multidisciplinary health promotion programs in the organizational environment. Maintaining a collaborative work environment favors interpersonal relationships ${ }^{23,27}$.

Furthermore, regarding the development of coping attitudes, it is apparent from the CSD, that in addition to the problem focused strategies, nurses develop efforts focused on emotion in an attempt to reduce the sensation of physical and psychological exhaustion evidenced by attitudes of distancing, escape from the problem and the search for emotional support. With these strategies that 
focus on replacing or regulating the emotional impact of stress, satisfactory results are also observed as measures to regulate emotions, based on the development of withdrawal, avoidance and search for social support attitudes ${ }^{28,29}$.

Other emotion-focused strategies were identified in the practice of Ghanaian nurses from Akwatia and reveal the use of work intervals, meditation, physical exercises and the use of relaxation techniques. It is noted that nurses who implement such strategies have fewer problems related to mental health, such as anxiety, depression and negative feelings ${ }^{30}$.

Aspects such as healthy eating, rest, adopting leisure activities, investing in maintaining sleep quality, psychotherapy, self-knowledge, pleasurable activities, added to the assessment of quality of life, reassessment of the limit of tolerance and individual requirement, development of relational skills (dialogue) and less conflicting coexistence with people and groups have been recognized as complementary ways of coping with stressors ${ }^{6,27}$. It is important to highlight that these complementary forms are strategies that can be used in order to relieve tensions, being considered palliative, as they do not involve the problem (professional stress) itself, but are focused on emotion.

It is important to highlight that the coping styles expressed in the statements of the HEU nurses and categorized a priori are not exclusive, as the possibilities of different coping strategies can be used at the same time, which indicates a cross-breeding of coping used to deal with stressful situations in the HEU context. Thus, the grouping of the different coping strategies are intertwined so that the regulation of anxiety (emotion focused coping), will allow nurses to focus on making a decision (problem focused coping). This cyclical process permeates a review of underlying values and existential objectives (focused coping), giving rise to a prediction and review of life goals, whose objectives are not trivial, but are already at underlying levels from the individual's independence. ${ }^{14}$

This result is relevant, considering that the different ways of reacting and solving problems favor the management of stressors in user care and in the management of services and also in well-being. Nurses, in their work process at the HEU, use multiple coping strategies, consequently minimizing negative repercussions on their physical and mental health.

Thus, not only in the context of the HEU, but also in other units, coping, while presenting itself as expectation, enables stress management, seeking to face it in a way that mitigates or avoids the consequences of stress, or even learn to live together in a way that influences the individual and the quality of personal and professional life ${ }^{3}$. Thus, it is learned that coping mechanisms are important for coping with stress, thus constituting perspectives and expectations for the quality of life of nurses working at HEU.

There are limitations in the study in that it presents a particular scenario of a specific sector of the hospital context, in which nurses were accessed in the work environment to carry out the research, a fact that may have influenced the data collection. However, the findings reveal density and prove to be substantial for knowledge about the phenomenon. When recognizing the need to expand the object, it is suggested to expand the investigations from the perspective of understanding the limit between the stressor and the triggering of stress, in an attempt to analyze the impact on psychosomatic, social and work repercussions and, consequently, the strengthened recognition of the coping strategies to be performed by nurses in other scenarios and also by organizations. 


\section{CONCLUSION}

The results of this study allowed to analyze the coping strategies used by nurses from the HEU, based on the knowledge of the situations that generate stress and the social, work and psychosomatic repercussions caused by the stressors experienced in the day to day work.

Coping strategies related to stress in the HEU are essential and indispensable measures which avoid the increase in stress levels and the triggering of negative repercussions on the nursing work process.

The study indicates that it is necessary to work on stress related coping effectively and manage the response to stressful demands and that nurses from the HEU exercise different coping strategies that are interconnected between problem-centered strategies and emotion-centered strategies, which minimize negative repercussions on physical and mental health.

\section{REFERENCES}

1. Souza SBC, Milioni KC, Dornelles TM. Analysis of the complexity degree of care, stress and coping of nursing in a hospital in Rio Grande do Sul. Texto Contexto Enferm [Internet]. 2018 [cited 2020 May 18];27(4):e4150017. Available from: https://doi.org/10.1590/0104-07072018004150017

2. Ribeiro FMSS, Mussi FC, Pires CGS, Silva RM, Macedo TTS, Santos CAST. Stress level among undergraduate nursing students related to the training phase and sociodemographic factors. Rev Latino-Am Enfermagem [Internet]. 2020 [cited 2020 May 11];28:e3209. Available from: https:// doi.org/10.1590/1518-8345.3036.3209

3. Santana TS, Servo MLS, Sousa AR. Estresse no processo de trabalho da enfermeira em emergência hospitalar. Rev Baiana Saúde Pública [Internet]. 2018 [cited 2020 May 11];42(Suppl 1): 163-7. Available from: https://doi.org/10.22278/2318-2660.2018.v42.n0.a2876

4. Teixeira GS, Silveira RCP, Mininel VA, Moraes JT, Ribeiro IKS. Quality of life at work and occupational stress of nursing in an emergency care unit. Texto Contexto Enferm [Internet]. 2019 [cited 2020 May 01];28:e20180298. Available from: https://doi.org/10.1590/1980-265XTCE-2018-0298

5. Maharaj S, Lees T, Lal S. Prevalence and risk factors of depression, anxiety, and stress in a cohort of Australian nurses. Int J Environ Res Saúde Pública [Internet]. 2018 [cited 2020 May 10];16(1):61. Available from: https://doi.org/10.3390/ijerph16010061

6. Adelaide MAO, Yennuten $P$, Theresa B, Atswei AK. Stress and coping strategies among nurse managers. J Nurs Educ Pract [Internet]. 2020 [cited 2020 May 15];10(2):39-48. Available from: https://doi.org/10.5430/jnep.v10n2p39

7. Chang Y, Chan HJ. Optimism and proactive Coping in relation to burnout among nurses. J Nurs Manag [Internet]. 2015 [cited 2020 May 15];23(3):401-8. Available from: https://doi.org/10.1111/ jonm.12148

8. Ribeiro RPO, Marziale MHP, Martins JT, Ribeiro PHV, Robazzi MLCC, Dalmas JC. Prevalence of metabolic syndrome among nursing personnel and its association with occupational stress, anxiety and depression. Rev Latino-Am Enfermagem [Internet]. 2015 [cited 2020 May 27];23(3):435-40. Available from: https://doi.org/10.1590/0104-1169.0383.2573

9. Lazarus RS, Folkman S. Coping and adaptation. In: Gentry WD, ed. Handbook of Behavioral Medicine. New York (US): The Guilford Press; 1984. p. 282-325.

10. Ribeiro RM, Pompeo DA, Pinto MH, Ribeiro RCHM. Estratégias de enfrentamento dos enfermeiros em serviço hospitalar de emergência. Acta Paul Enferm [Internet]. 2015 [cited 2020 May 11];28(3):216-23. Available from: https://doi.org/10.1590/1982-0194201500037 
11. Lefevre F, Lefevre AMC. O sujeito coletivo que fala. Comunic, Saúde, Educ [Internet]. 2006 [cited 2020 May 11];10(20):517-24. Available from: https://doi.org/10.1590/S1414-32832006000200017

12. Lipp MEN. Stress emocional: esboço da teoria de "temas da vida". In: Lipp MEN, ed. O stress no Brasil: pesquisas avançadas. Campinas SP: Papirus; 2004. p. 17-30.

13. Teixeira CAB, Gherardi-Donato ECS, Pereira SS, Cardoso L, Reisdorfer E. Estrés laboral y estrategias de afrontamiento entre los profesionales de enfermería hospitalaria. Enferm Global [Internet]. 2016; [cited 2020 May 27];15(4):288-98. Available from: http://scielo.isciii.es/scielo. php?script=sci_arttext\&pid=S1695-61412016000400012\&Ing=es

14. Folkman S. Stress, coping, and hope. Psycho-Oncology [Internet]. 2010 [cited 2020 May 27];19(9):901-8. Available from: https://doi.org/10.1002/pon.1836

15. Achiharu M, Hidenori A, Sawako S. Nurse managers stress and coping. Open Journal of Nursing [Internet]. 2015 [cited 2020 May 27];5:957-64. Available from: https://doi.org/10.4236/ ojn.2015.511101

16. Guedes CR, Rangel VM, Camargo JK. O movimento da medicina psicossomática no Brasil: a trajetória teórica e institucional de Danilo Perestrello. Hist Cienc Saude-Manguinhos [Internet]. 2020 [cited 2020 Dec 15];27(3):803-17. Available from: https://doi.org/10.1590/s010459702020000400006

17. Azevedo BDS, Nery AA, Cardoso JP. Estresse ocupacional e insatisfação com a qualidade de vida no trabalho da enfermagem. Texto Contexto Enferm [Internet]. 2017 [cited 2020 May 11];26(1):e3940015. Available from: https://doi.org/10.1590/0104-07072017003940015

18. Santos TA, Santos HS, Sampaio ES, Melo CMM, Souza EA, Pires CGS. Intensity of nursing work in public hospitals. Rev Latino-Am Enfermagem [Internet]. 2020 [cited 2020 May 05];28:e3267. Available from: https://doi.org/10.1590/1518-8345.3221.3267

19. Pereira SS, Teixeira CAB, Reisdorfer E, Vieira MV, Donato ECSG, Cardoso L. A relação entre estressores ocupacionais e estratégias de enfrentamento em profissionais de nível técnico de enfermagem. Texto Contexto Enferm [Internet]. 2016 [cited 2020 May 11];25(4):e2920014. Available from: https://doi.org/10.1590/0104-07072016002920014

20. Varela A, Pereira A, Pereira A, Santos JC. Distress psicológico: contributos para a adaptação portuguesa do sq-48. Psic Saúde Doenças [Internet]. 2017 [cited 2020 Dec 16];18(2):278-86. Available from: https://doi.org/10.15309/17psd180201

21. Dias EM, Pais-Ribeiro JL. O modelo de coping de Folkman e Lazarus: aspectos históricos e conceituais. Rev Psicol Saúde [Internet]; 2019 [cited 2020 May 11];11(2):55-66. Available from: https://doi.org/10.20435/pssa.v11i2.642

22. Kolhs M, Olschowsky A, Barreta NL, Schimerfening J, Vargas R, Busnello GF. Nursing in urgency and emergency: between pleasure and suffering. Rev Fund Care Online [2017]. [cited 2020 May 27];9(2):422-31. Available from: https://doi.org/10.9789/2175-5361.2017.v9i2.422-431

23. Antoniolli L, Guanilo ME, Martins CL, Amestoy SC, Longaray TM, Souza SB. Coping e estresse na equipe de enfermagem de um centro de tratamento de queimados. Rev Bras Queimaduras [Internet]. 2017 [cited 2020 May 12];16(3):174-80. Available from: http://hdl.handle.net/10183/212334

24. Souza RC, Silva SM, Costa MLAS. Occupational stress in hospital settings: review of coping strategies of nursing professionals. Rev Bras Med [Internet]. 2018 [cited 2020 May 27];16(4): 493-502. Available from: https://doi.org/10.5327/Z1679443520180279

25. Dias CA, Santos DC, Matias LO, Servo MLS, Santana CLA, Tanaka LH. Representações de supervisão na perspectiva dos enfermeiros coordenadores de um hospital de ensino. Rev Baiana Enferm [Internet]. 2018 [cited 2020 May 27]; 2:e27422. Available from: https://doi.org/10.18471/ rbe.v32.27422 
26. Jeremy PJ, Alia JCJ. Parker G, Marisa E, Marotta EM, Modupe A. Optimizing stress responses with reappraisal and mindset interventions: an integrated model. Anxiety, Stress \& Coping [Internet]. 2018 [cited 2020 May 27];31(3):245-61. Available from: https://doi.org/10.1080/1061 5806.2018.1442615

27. Reis CD, Amestoy SC, Silva GTR, Santos SD, Varanda PAG, Santos IAR et al. Situações estressoras e estratégias de enfrentamento adotadas por enfermeiras líderes. Acta Paul Enferm [Internet]. 2020 [cited 2020 May 12];33:eAPE20190099. Available from: https://doi.org/10.37689/ acta-ape/2020ao0099

28. Perera CK, Pandey R, Srivastava AK. Role of religion and spirituality in stress management among nurses. Psychol Stud [Internet]. 2018 [cited 2020 May 20];63:187-99. Available from: https://doi.org/10.1007/s12646-018-0454-x

29. Ewa K, Marcin J. Positive orientation and strategies for coping with stress as predictors of professional burnout among polish nurses. Int J Environ Res Public Health [Internet]. 2019 [cited 2020 May 20];16:4264. Available from: https://doi.org/10.3390/ijerph16214264

30. Adzakpah G, Laar AS, Fiadjoe HS. Occupational Stress and its management among nurses at St. Dominic hospital, Akwatia, Ghana. Health Sci J [Internet]. 2016 [cited 2020 May 27];10(6):467. Available from: https://doi.org/10.21767/1791-809X.1000467 


\section{NOTES}

\section{ORIGIN OF THE ARTICLE}

Extracted from the Macro-Research Project - Stress in the nursing supervision work process in Feira de Santana-BA, linked to the Professional Master's Program in Nursing at the Universidade Estadual de Feira de Santana, 2020.

\section{CONTRIBUTION OF AUTHORITY}

Study design: Santana TS, Servo MLS.

Data collection: Santana TS.

Data analysis and interpretation: Santana TS, Servo MLS, Sousa AR.

Discussion of the results: Santana TS, Servo MLS, Sousa AR.

Writing and/or critical review of the content: Santana TS, Servo MLS, Sousa AR, Fontoura EG, Góis RMO, Merces MC.

Review and final approval of the final version: Santana TS, Servo MLS, Sousa AR, Fontoura EG, Góis RMO, Merces MC.

\section{FUNDING INFORMATION}

Fundação de Amparo à Pesquisa da Bahia (Fapesb), approved by CONSEPE Resolution 49/2004.

\section{APPROVAL OF ETHICS COMMITTEE IN RESEARCH}

Approved by the Research Ethics Committee of the Faculdade Maria Milza, opinion no.1,997,878/2017, Certificate of Presentation for Ethical Appreciation 66184217.7.0000.5025.

\section{CONFLICT OF INTEREST}

There is no conflict of interest.

\section{EDITORS}

Associated Editors: Selma Regina de Andrade, Gisele Cristina Manfrini, Laura Cavalcanti de Farias Brehmer, Ana Izabel Jatobá de Souza.

Editor-in-chief: Roberta Costa.

\section{HISTORICAL}

Received: October 01, 2020.

Approved: February 04, 2021.

\section{CORRESPONDING AUTHOR}

Thiago da Silva Santana

tssantana@uefs.br 